\title{
Pathological Survey on Disease Incidence and Severity of Major Diseases on Tomato and Chilli Crops Grown in Sub Zoba Hamelmalo, Eritrea
}

\author{
Sethumadhava Rao, Syed Danish, Sham Keflemariam, Haben Tesfagergish, Rahwa \\ Tesfamariam, Tomas Habtemariam \\ Department of Plant Protection, Hamelmalo Agricultural College, Keren, Eritrea \\ sethumadhava.g@gmail.com
}

\begin{abstract}
This survey has been conducted to observe the disease incidence and severity on the major vegetables like tomato and chilli, cultivated in sub zoba Hamelmalo during two different seasons i.e. autumn (Qewi) and winter (Hagay). The surveyed areas were Wazntet, Awrari, Basheri, Genfelom and Hamelmalo by selecting two farms from each village. The crops were affected by different diseases such as early blight, late blight, powdery mildew, wilt, blossom end rot and leaf curl in tomato and damping off, leaf curl, bacterial leaf spot in chilies. The symptoms have been observed and compared the disease incidence and severity among the selected farms of the villages, occurred throughout the various phenological stages of the plants. The present survey revealed that there was no any significant difference between the surveyed areas, based on the diseases incidence and severity which is calculated at that particular time. Percentage of disease incidence and severity of tomato was higher in Basheri and Awrari, while the both disease intensities of chillies were recorded maximum during Qewi season in Basheri and Genfelom. In tomato and chillies, the percentage of disease incidence showed more than 77\% in all villages during Hagay season but the severity was observed between 20 and $60 \%$. The reasons for those results are low educational level, no proper irrigation, unavailability of fertilizers and lack of chemicals for controlling the diseases
\end{abstract}

Keywords: Disease Incidence; Disease Severity: Tomato; Chilli; Hamelmalo

Abbreviations:

USA:

United States of America

GDP:

Gross Domestic Product

MoA :

Ministry of Agriculture

GoSE:

Government of the State of Eritrea

PDA:

Potato Dextrose Agar

PDI:

Percentage of disease incidence

PDS:

Percentage of disease severity

L.S.D:

least significant difference

C.V:

coefficient variation

ha:

hectare

$\mathrm{mt}$ :

metric tons

\section{INTRODUCTION}

Vegetables are the cheapest and richest sources of calories, natural vitamins, minerals, dietary fiber and are therefore, named as "protected foods" which are essential to tackle the problems of malnutrition and improve quality of life [1]. As compared to orcharding, the vegetable industry is characterized by its flexibility, because most vegetables are annuals, and cultivars can be changed according to the requirements of specific agro-climatic condition from year to year as per need. Suitable $\mathrm{pH}$ values for soils carrying intensively cropped vegetables are in the range 5.3-7.5 although some crops such as tomato and chili can tolerate slightly acid soil. Most countries of the world have made tremendous progress in the field of vegetable growing. China is the largest producer of vegetables (about 35 percent to the world's vegetable production), India is the second and followed by USA, Turkey and Japan [2].

According to Osan, 2009 [3], in Eritrea, agriculture is the mainstay of about $60 \%$ of Eritreans for income and food. The sector accounts for about $16 \%$ of the Gross Domestic Product (GDP), and 
contributes $20 \%$ to $30 \%$ of the country's export earnings. The Government of the State of Eritrea (GoSE) has made agriculture its top priority and through the Ministry of Agriculture (MoA) has extended its structure to regional (Zoba) and sub-regional (Sub Zoba) level. Some farmers grow vegetables under irrigation during the winter dry season, where water is available. The area crossed by the river 'Anseba' is particularly suitable for production under irrigation of citrus, grapes, a wide range of tropical fruits and all kind of vegetables [4], [5]. Table 1 shows the area and production of tomatoes and Chillies in Eritrea as well as in Zoba Anseba.

Table1: Total Area and Production of Tomato and Chili in Eritrea and in Zoba Anseba

\begin{tabular}{|l|l|l|l|l|}
\hline Types of Vegetables & \multicolumn{2}{|l|}{ Eritrea } & Zoba Anseba \\
\hline & Area (ha) & Production (mt) & Area (ha) & Production (mt) \\
\hline Tomato & 3740 & 96228 & 617 & 6663 \\
\hline Chilli & 3550 & 30309 & 300 & 874 \\
\hline
\end{tabular}

*ha=hectare; $m$ t=metric tons; [6].

Vegetables contain a great variety of other phytochemicals (bioactive non-nutrient plant compounds), some of which have been claimed to have antioxidant, antibacterial, antifungal, antiviral and anticarcinogenic properties. Tomato and Chillies are the major vegetables grown in sub zoba Hamelmalo. Survey has been taken on the diseases major vegetables cultivated in this region, including their disease incidence and severity occurred among them.

Diseases are classified in to groups according to the pathogen which causes them. The most common disease are caused by fungi but those due to bacteria and viruses may be series, there is also a class of disease called physiological disease, there are not caused by pathogen but are due to various internal disorder of the plant which may be associated with the environment, nutrition or even irregular watering as with 'blossom end rot' of tomato. Bacterial Canker, Bacterial Spot symptoms on tomato, Bacterial Specks caused by Pseudomonas syringae pv. tomato etc. (Rice et al, 1990). Curly top, pepper spotted wilt on chillies etc are the very economic important diseases caused by viruses [7].

Many diseases and disorders can affect the vegetables during the growing season in sub zoba Hamelmalo. Diseases have been devastating the vegetables in sub zoba Hamelmalo and results in low yield and economic losses to the farmers. Hence, this survey which describes the disease cycle, symptoms and management of common problems of tomato and chili, occurred in the orchards of tomato and Chillies in the selected villages.

Tomato (Lycopersicon esculentum Mill) which belongs to Solanaceae family is herbaceous sprawling plant growing to 1-3 m in height with weak woody stem. In Eritrea, cultivated tomato, Solanum lycopersicum, is commercially one of the most important vegetables together with onion, potato and pepper. Tomato as a "protective foods" is included in the top four priority vegetable crops in the country. The production is more equally distributed over all administrative zones than that of other vegetable crops grown in Eritrea. The average yield of tomato in Eritrea is about $15 \mathrm{~kg} / \mathrm{ha}$ [8], whereas average yields are $19.1 \mathrm{~kg} / \mathrm{ha}$ in Africa, $23 \mathrm{~kg} / \mathrm{ha}$ in Asia and $27.2 \mathrm{~kg} / \mathrm{ha}$ in the entire world [9]. Post-harvest losses of tomato, mainly caused by physiological deterioration and bruising, can amount to more than $30 \%$ of the production and in general the quality of tomatoes has never been given due attention [8].

Chillies (Capsicum annuum L.) are green or dried fruits of pungent forms of which is widely cultivated throughout the world, more specifically in the tropical and sub-tropical regions. Chillies are the most popular vegetable crop in zoba Anseba. Chillies are used as ingredients to add flavor and color to most dishes. They are high in vitamin A and C, calcium and iron and can be used as a medicine to treat asthma, coughs and sore throats. Though it has much importance, many diseases and disorders can affect chillies during the growing season. This survey describes the symptoms and management of common problems found in orchards found in sub zoba Hamelmalo. These oldest cultivated crops on this continent grow well in areas where the average temperature is $24{ }^{\circ} \mathrm{C}$ for at least 4 to 5 months of the year. Chillies can be grown in a wide range of soils. The optimum soil for production is sandy loam, deeper than $400 \mathrm{~mm}$ with a $\mathrm{pH}$ between 5.5 and 7.0.

Tomato and Chillies are one of the economically important vegetables of Eritrea produced along the river bank of Anseba. Even if they produce enough fruits, they are dropped in large amounts before they reach maturity which is a great economic loss to the farmers. Diseases are a major limiting 
factor for their production. Hence it is important to identify the major diseases of tomato and chili and applying control measure, looking for the best possible solutions.

The main objective of this study is to survey of various diseases and its intensity on tomato and chillies cultivated in the fields of Sub Zoba Hamelmalo, Eritrea. The specific objectives are: to determine the incidence and severity of diseases of tomato and chillies caused by various pathogens at different seasons; and to identify the problems of farmers and give recommendations on how to solve those problems.

\section{MATERIALS AND MeTHODS}

\subsection{Site Description and Altitude}

Hamelmalo is located at $12 \mathrm{~km}$ north east of Keren town on the Keren-Nakfa road on the bank of the river Hamelmalo at $15^{\circ} 53^{\prime} \mathrm{N}$ latitude and $38^{\circ} 66^{\prime} \mathrm{E}$ longitude and an elevation of 1292 meters above sea level. The average altitude of sub zoba Hamelmalo is $1330 \mathrm{~m}$ above mean sea level. Most of the areas are dominated by hills and mountains.

\subsection{Climate}

Climate is fluctuating in the whole year in sub Zoba Hamelmalo, It is cold from November to March while it is hot from April to June, and the remaining months are with moderate temperature. The total annual average rainfall is about $497.2 \mathrm{~mm}$ and the major amount of rainfall occurs between June and August. The average mean annual temperature varies from $16^{\circ}$ to $38^{\circ} \mathrm{C}[10]$.

\subsection{Soil}

The soil of the sub Zoba is predominantly sandy loam. The $\mathrm{pH}$ values for these soils are in the range of 5.5 up to 7.5, suitable for vegetable cultivation.

\section{Survey Areas, Collecting Data ANd Samples}

The survey has been conducted in two seasons, i.e. Autumn season (August to November) and winter season (January to March) on the crops of tomato and chillies which are grown in sub Zoba Hamelmalo. The survey has been executed with local farmers in selected five villages, i.e. Wazntet, Basheri, Awrari, Genfelom and Hamelmalo, (these villages are 1 up to $3 \mathrm{~km}$ apart) where these vegetables being grown. From each village two farmers have been selected for interviewing by using questionnaires, discussion with representative farmers and some experts and also consulted the relevant persons who work in the Ministry of Agriculture found in zoba Anseba and sub Zoba Hamelmalo; and also interviewed vegetable traders who market these crops, to determine the disease incidence and severity of the major diseases caused by various pathogens in sub Zoba Hamelmalo.

\section{Isolation ANd IDENTIFICATION OF THE PATHOGEN}

Infected plant samples of leaves, fruits and twigs have been collected in brown paper packets and brought to laboratory for identification of pathogens. All materials which are used in this experiment were sterilized using ethyl alcohol except the samples. The diseased parts were cut into small pieces of $3 \mathrm{~mm}$ diameter with some healthy part. The small pieces were washed with tap water and surface sterilized with $10 \% \mathrm{NaOCl}$ for 30 to $60 \mathrm{sec}$, again rinsed with sterile water and blotted to dry on clean tissue paper. After drying, three pieces were aseptically placed into Petri dishes containing Potato Dextrose Agar (PDA) medium. Then, the inoculated Petri dishes have been marked with name of the sample and date of inoculation and incubated at a temperature of $25^{\circ} \mathrm{C}$ for 5 days, until pathogen proliferation on medium surface [11].

Fungal identifications were carried out on the basis of characterization of colonies and have also been examined under a compound microscope with 40X magnification [12] and [13].

\section{Statistics And Data Analysis}

The common and important disease observations were surveyed and the disease incidence and severity were assessed randomly on tomato and pepper plants. Representative samples, based on visual symptoms of the disease were brought from each field at random as per methods described by Yonghao Li [14]. The selected sites were approximately equal distance from each other along the sampling pathway.

The formulae in calculating the disease incidence and severity are: 
Sethumadhava Rao et al.

Percentage of disease incidence $(\mathrm{PDI})=\frac{\text { Total Number of Infected Plants }}{\text { Total Number of Plants Assesed }} \times 100$

Percentage of disease severity $(\mathrm{PDS})=\frac{\text { Number of Individual Raitngs }}{\text { Number of Plants Assesed }} \times \frac{100}{\text { Maximum Scale }}$

The maximum rating scale (1-5) has been used for assessment of the disease severity is:

\begin{tabular}{|l|l|}
\hline Rating Scale & Disease Percentage \\
\hline 1 & $1-5$ \\
\hline 2 & $5-25$ \\
\hline 3 & $25-50$ \\
\hline 4 & $50-75$ \\
\hline 5 & $75-100$ \\
\hline
\end{tabular}

The data have been collected from five different fields in Hamelmalo sub zone and visited four times at an interval of three weeks in each field. All the collected data were subjected to analysis of variance at an end of the study by using GenStat Release 10.3 (2011) software application.

\section{RESUlTS AND DISCUSSION}

According to the Ministry of Agriculture of zoba Anseba, tomato, chili and okra were the major vegetables cultivated in sub zoba Hamalmalo. But okra started to reduce its production by $9 \%$ every year [6], due to several diseases and physiological disorders. It could be this reason why the most of the farmers stopped cultivating okra.

\section{COMMON AND MAJOR DISEASES ON TOMATO}

The common diseases infected by fungal, bacterial and viral that are transmitted by pests ((Plates 1-3) are found in all surveyed villages i.e. Wazntet, Awrari, Genfelom, Basheri and Hamelmalo. Table 2 clearly indicating that the most of the diseases are caused by fungi. Early blight and late blight were the most common in all villages while the diseases caused by pests such as tomato borer and Septoria leaf spot rarely found. Powdery mildews were observed in both Wazntet and Genfelom villages.

Table2: Common diseases on Tomato in five selected villages in Sub Zoba Hamelmalo

\begin{tabular}{|c|c|c|c|c|}
\hline Wazntet & Awrari & Genfelom & Basheri & Hamelmalo \\
\hline Early blight ${ }^{(\mathrm{f})}$ & Blight ${ }^{(f)}$ & Leaf curl $^{(\mathrm{v})}$ & Leaf curl ${ }^{(\mathrm{v})}$ & Early Blight $^{(\mathbf{f})}$ \\
\hline Late blight ${ }^{(\mathrm{f})}$ & Leaf curl $^{(v)}$ & Bacterial wilt $^{(\mathrm{b})}$ & Bacterial wilt $^{(\mathrm{b})}$ & Late blight ${ }^{(\mathrm{f})}$ \\
\hline Leaf curl ${ }^{(v)}$ & Bacterial wilt $^{(\mathrm{b})}$ & Early blight ${ }^{(\mathbf{f})}$ & Early blight ${ }^{(\mathbf{f})}$ & Yellowing leaf ${ }^{(v)}$ \\
\hline Bacterial wilt $^{(\mathrm{b})}$ & Yellowing leaf ${ }^{(v)}$ & Late blight ${ }^{(\mathrm{f})}$ & Late blight ${ }^{(\mathbf{f})}$ & Fusarium wilt ${ }^{(\mathrm{f})}$ \\
\hline Fusarium wilt $^{(\mathrm{f})}$ & Fusarium wilt ${ }^{(\mathbf{f})}$ & Fusarium wilt ${ }^{(\mathbf{f})}$ & Tomato borer ${ }^{(p)}$ & Leaf curl ${ }^{(v)}$ \\
\hline Blossom end rot ${ }^{(\mathrm{d})}$ & Septoria leaf spot ${ }^{(\mathbf{f})}$ & Bacterial wilt $^{(b)}$ & 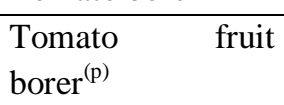 & $\begin{array}{l}\text { Tomato fruit borer } \\
\text { (p) }\end{array}$ \\
\hline \multirow[t]{2}{*}{ Powdery mildew $^{(\mathrm{f})}$} & Fruit cracking & Powdery mildew $^{(\mathbf{f})}$ & Blossom end $\operatorname{rot}^{(\mathrm{d})}$ & \\
\hline & & Blossom end $\operatorname{rot}^{(\mathbf{d})}$ & Yellowing leaf $^{(\mathrm{v})}$ & \\
\hline
\end{tabular}

${ }^{(f)}$ fungal diseases; ${ }^{\left({ }^{b}\right)}$ bacterial diseases; ${ }^{(v)}$ viral diseases; ${ }^{\left({ }^{p}\right)}$ pests and disorders; ${ }^{(d)}$ defects
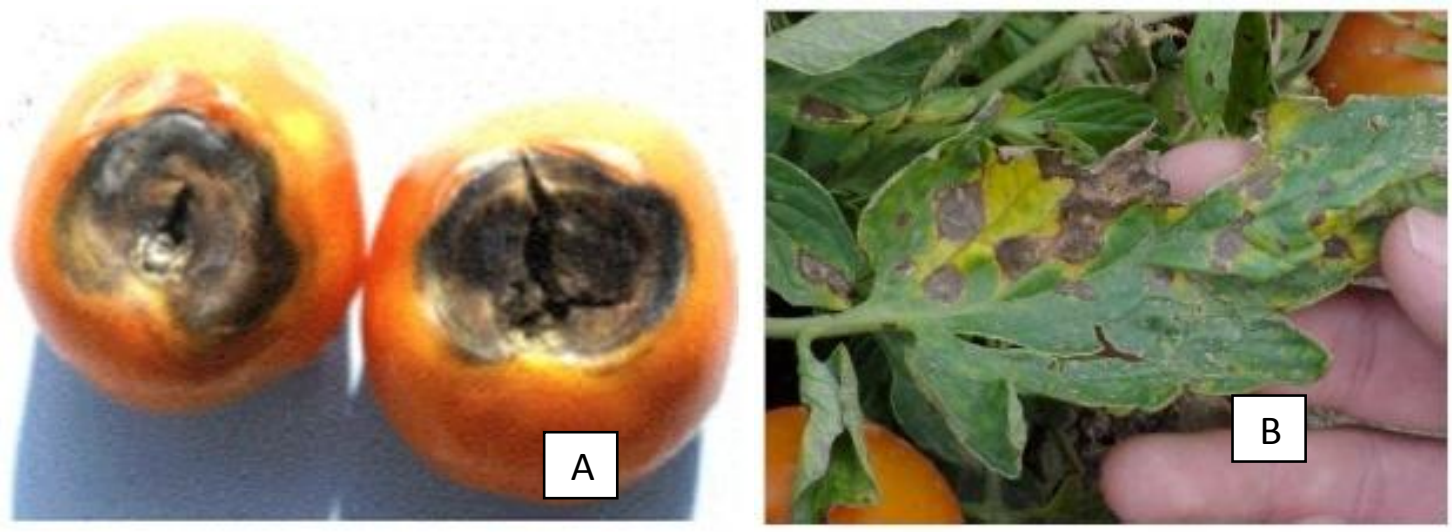
Pathological Survey on Disease Incidence and Severity of Major Diseases on Tomato and Chilli Crops Grown in Sub Zoba Hamelmalo, Eritrea
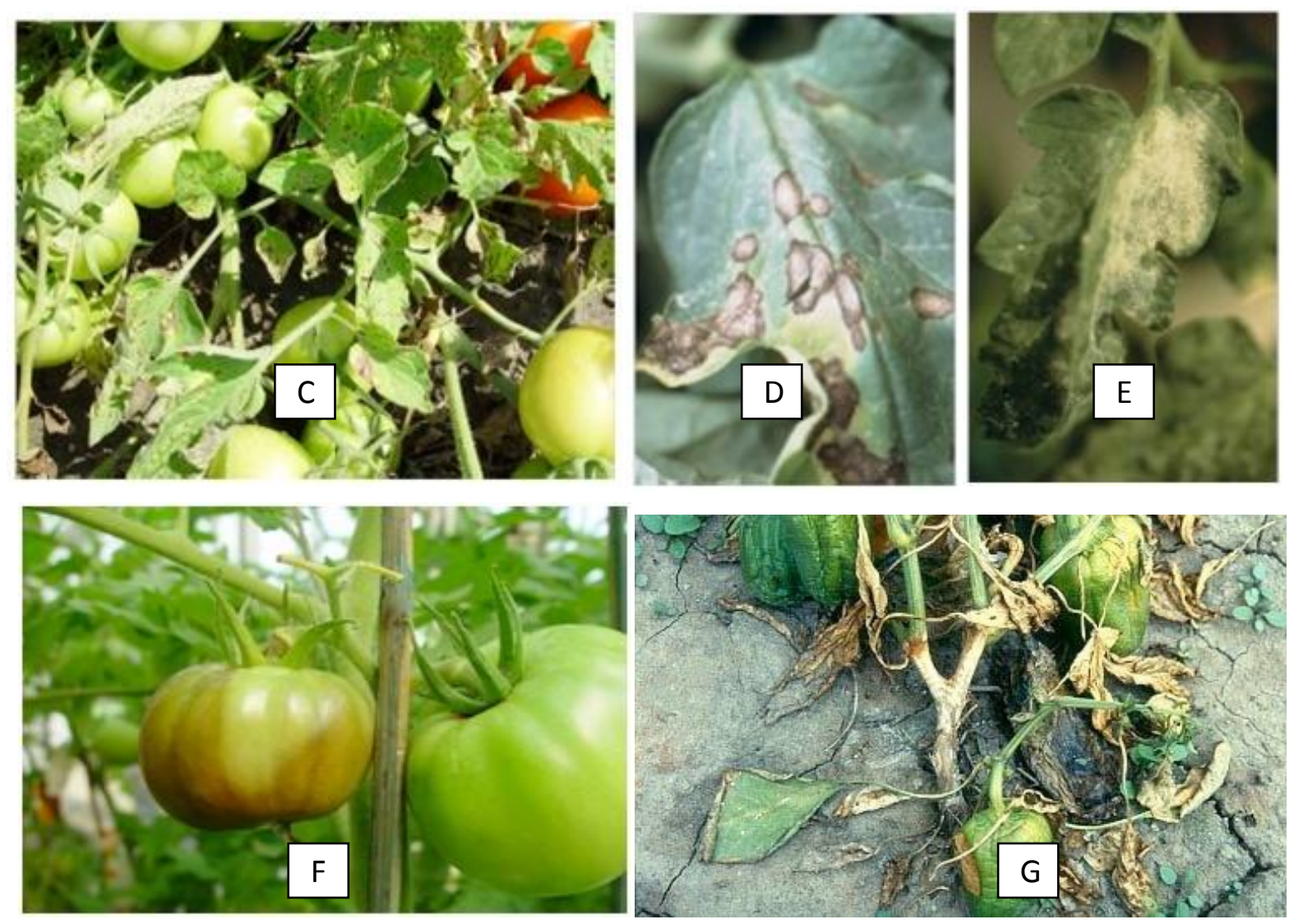

Plate1. Early Blight symptoms of tomato leaf (A) and fruits (B); Symptoms of Septoria Leaf Spot on tomato plant $(C)$, leaf (D) and Powdery Mildews (E); Buckeye Rot caused by Phytophthora capsici (F) and Timber Rot caused by Sclerotinia White Mold $(G)$.
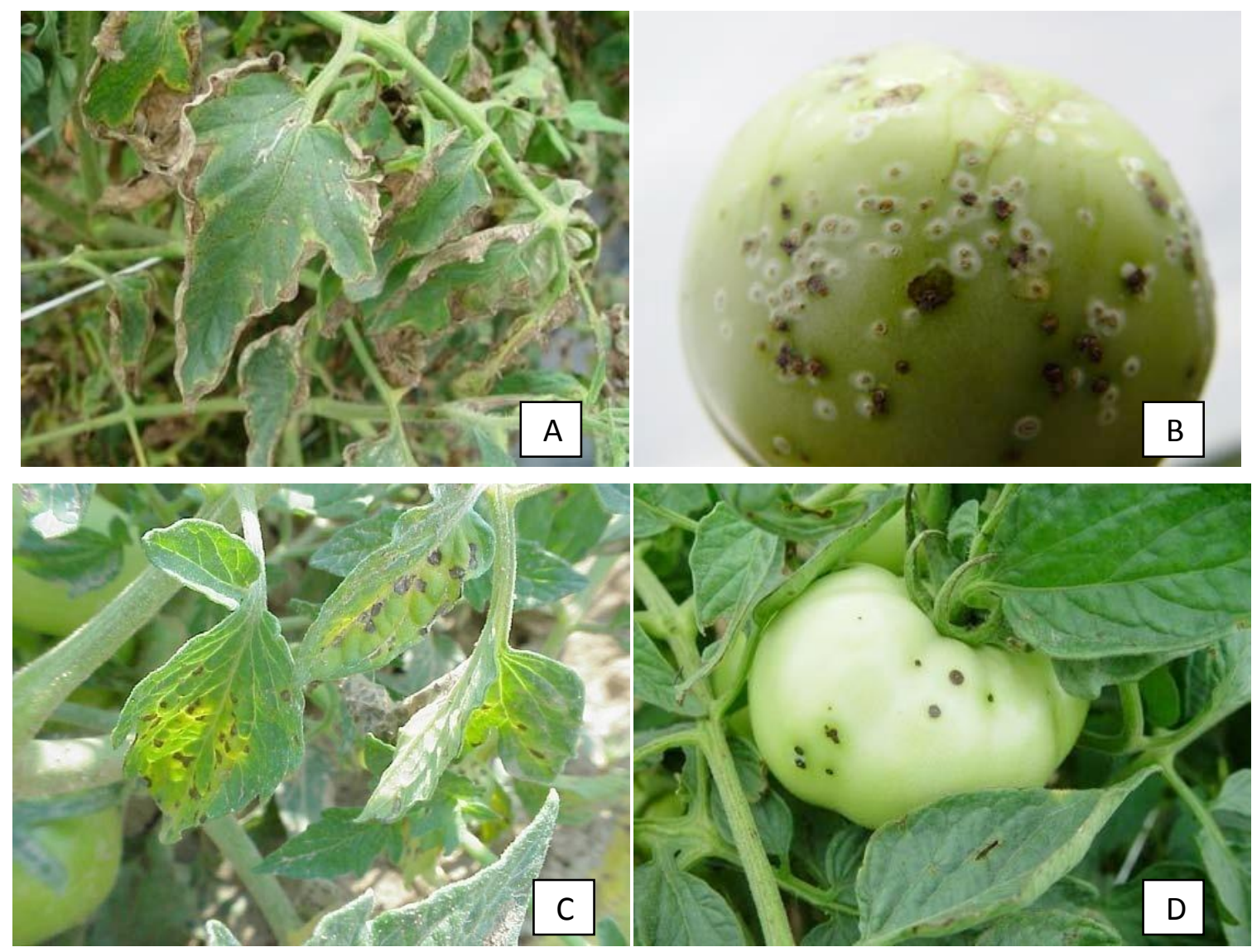


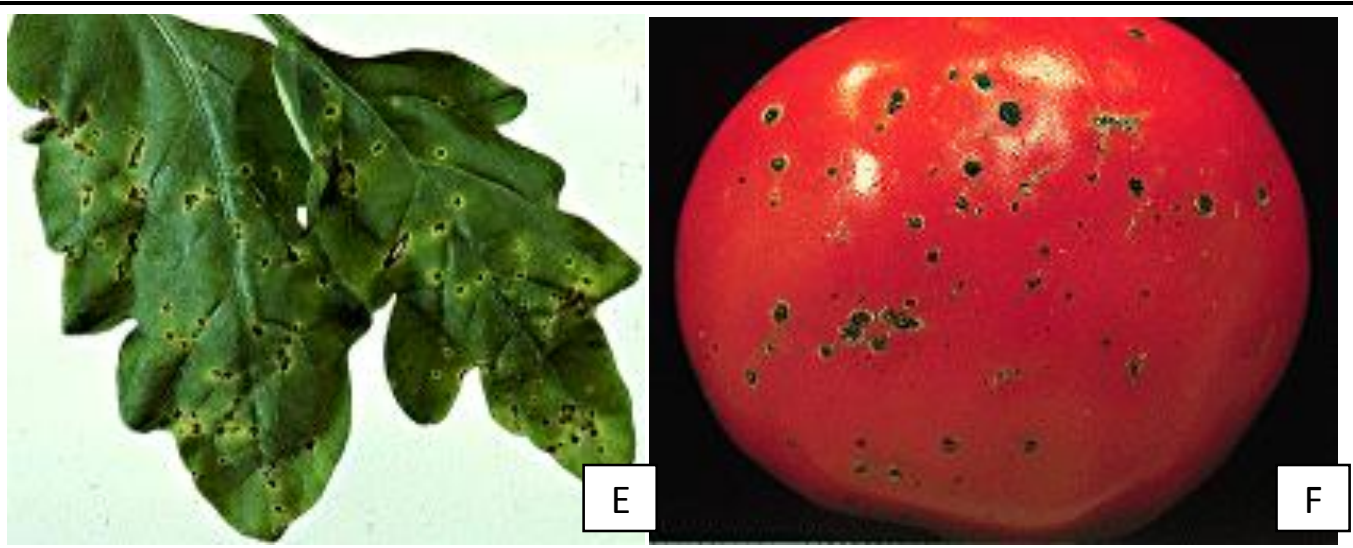

Plate2. Bacterial Canker on leaves (A) and fruit (B); Bacterial Spot symptoms on tomato (C and D); Bacterial Speck on leaves $(E)$ and fruit $(F)$ caused by Pseudomonas syringae pv. tomato
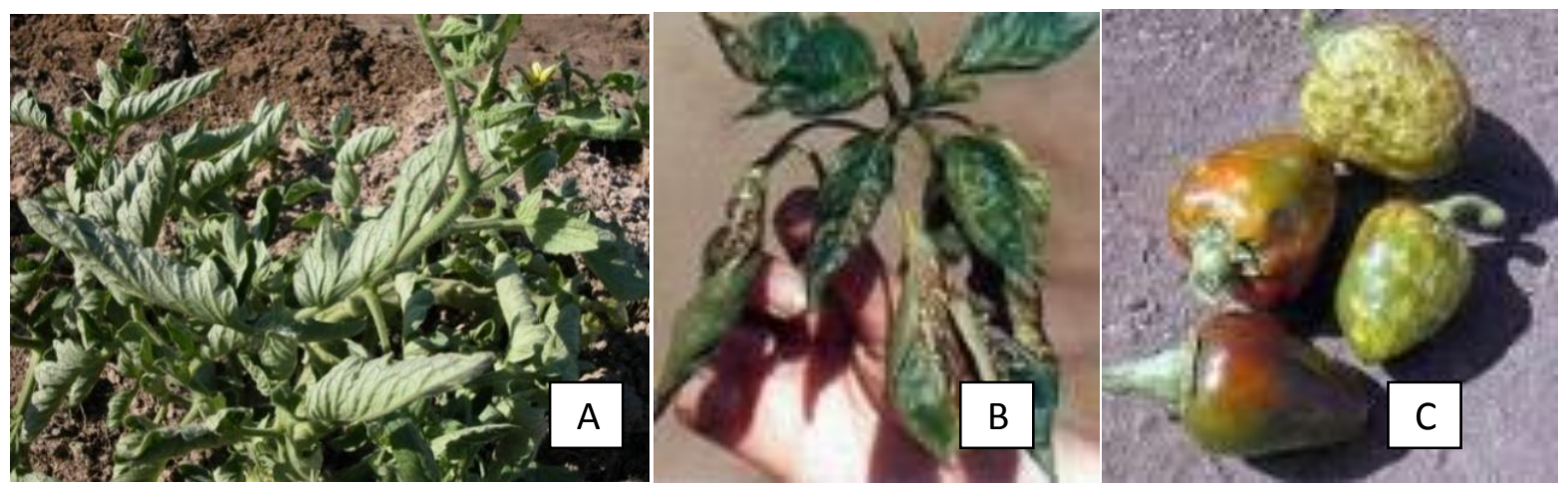

Plate3. Curly Top on tomato plant (A); and Pepper Spotted Wilt Virus on Chillies (B and C)

\section{The COMMON ANd MAJOR Diseases ON PEPPER:}

Damping off, yellowing leaf and leaf curl (Plates 4 and 5) have been observed in Awrari, Genfelom, Basheri and Hamelmalo villages. No diseases on pepper were recorded in Wazntet village in the sub zoba Hamelmalo (Table 3).

Table3: Common diseases on Pepper in five cultivating fields in Sub Zoba Hamelmalo

\begin{tabular}{|l|l|l|l|l|}
\hline Wazntet & Awrari & Genfelom & Basheri & Hamelmalo \\
\hline- & Damping off & Yellowing of leaf & Damping off & Yellowing leaf \\
\hline- & Yellowing leaf & Bacterial wilt & Yellowing leaf & Leaf curl \\
\hline- & Leaf curl & Damping off & Leaf curl & - \\
\hline
\end{tabular}
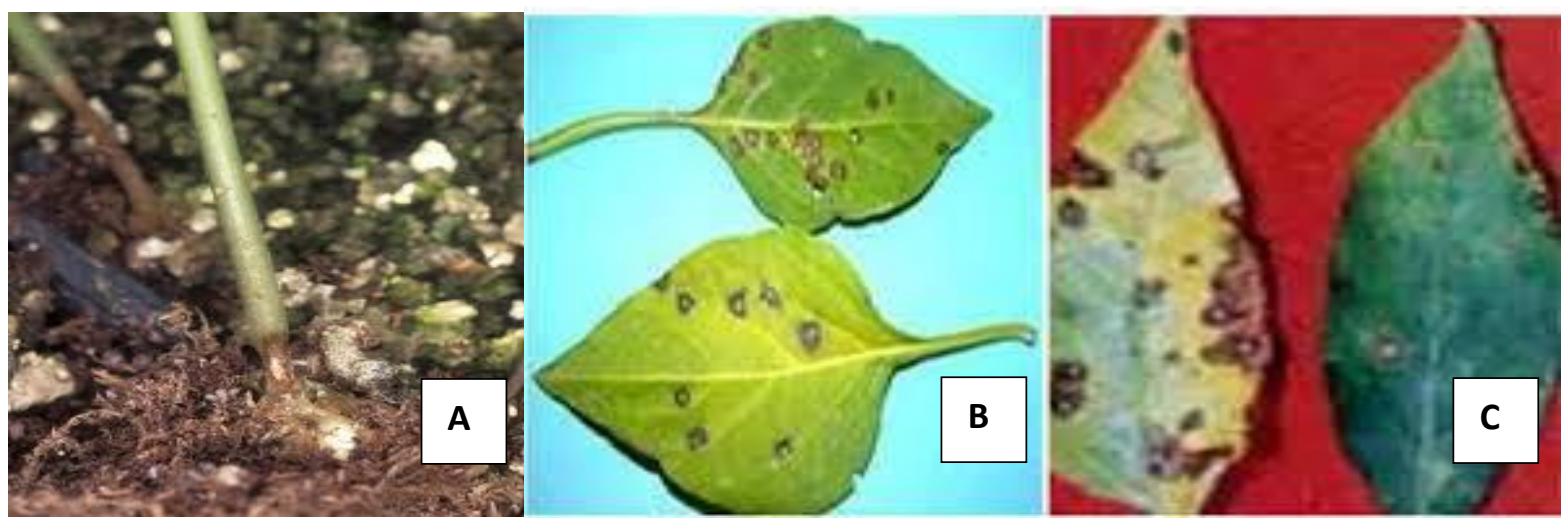

Plate4. Symptoms of Damping off at seedling stage (A); lesions on leaves (B and C); 
Pathological Survey on Disease Incidence and Severity of Major Diseases on Tomato and Chilli Crops Grown in Sub Zoba Hamelmalo, Eritrea
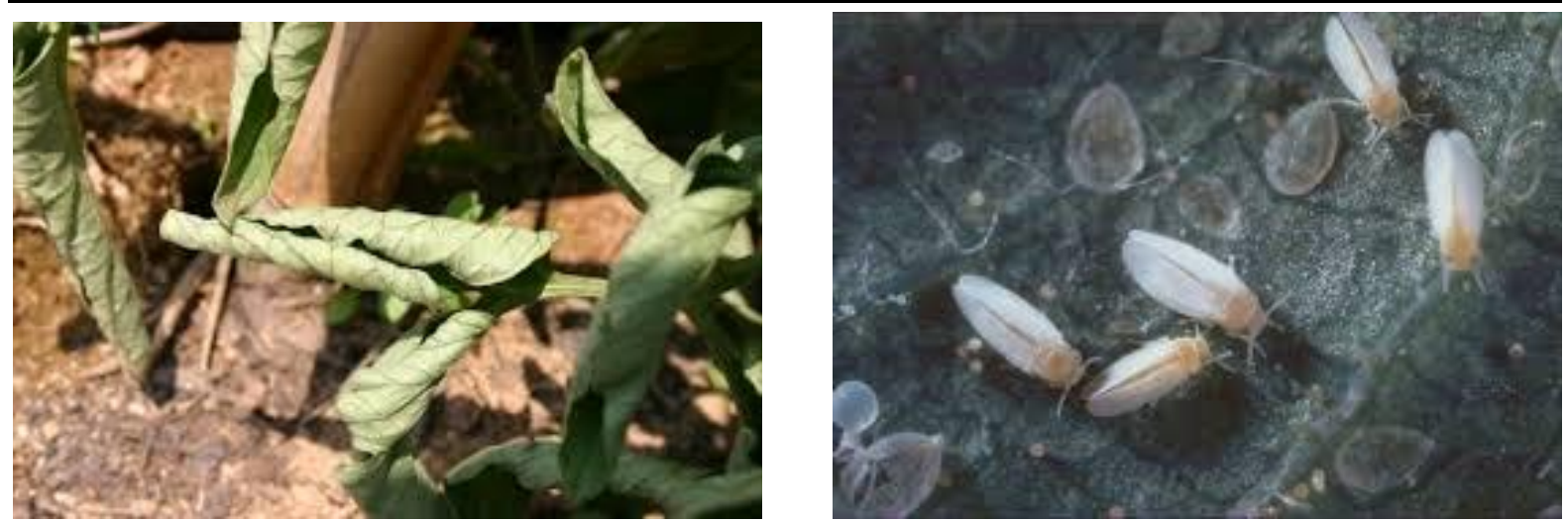

Plate5. Symptoms of leaf curl of chili and the vectors which transmit the diseases

The infected tomato and chilli samples were collected and inoculated in the media for the growth of the causing pathogen. Under the compound microscope, the causing organisms Alternaria spp.; Aspergillus spp.; Fusarium spp.; and Phytophthora spp. have been identified (Plate 6).
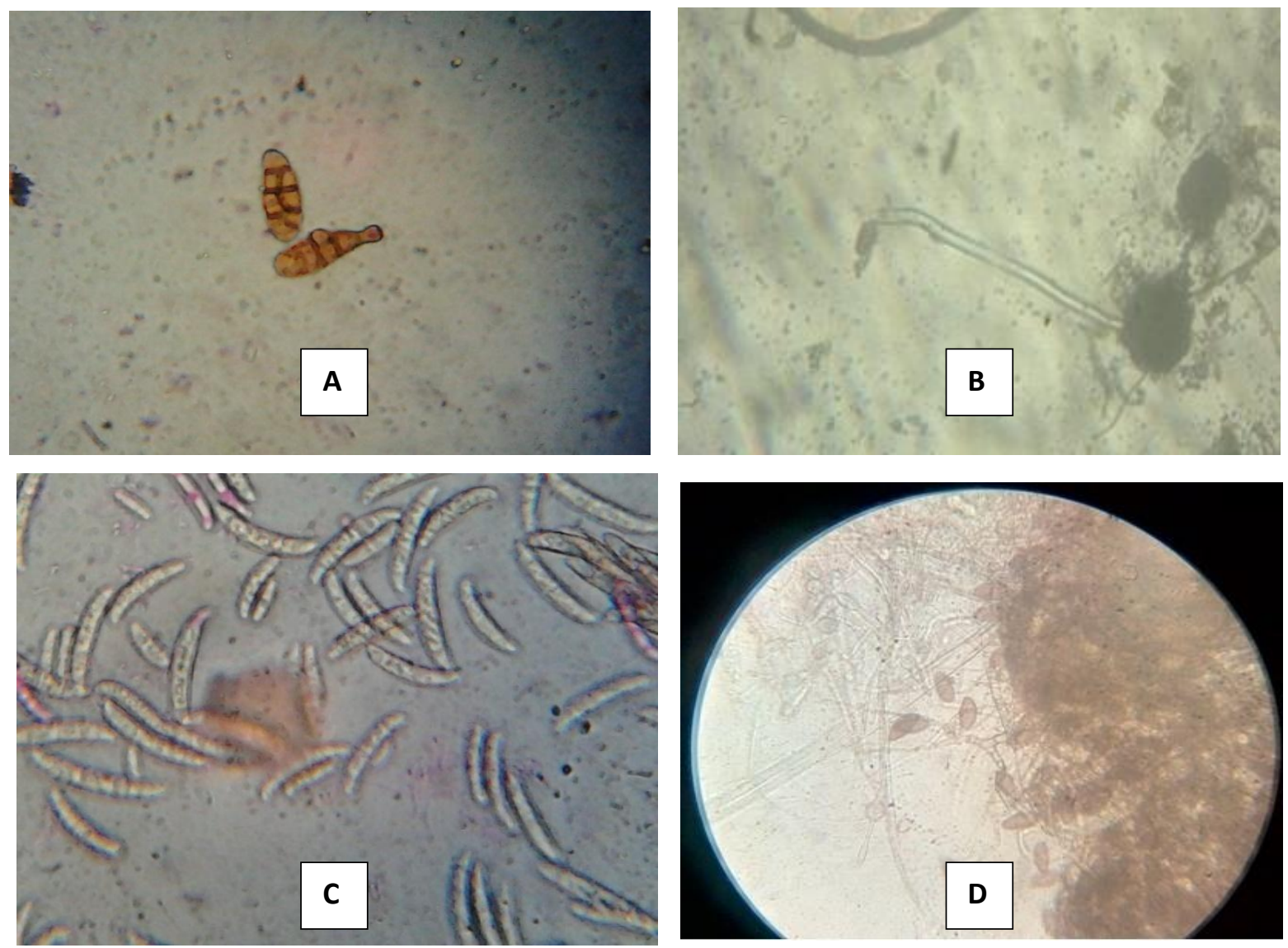

Plate6. Microscopic images of (A) Alternaria, (B) Aspergillus, (C) Fusarium and (D) Phytophthora

\section{Survey during Autumn (Qewi) and Winter (Hagay) Season}

The first observation was done during autumn season and the second survey has been taken place during winter season.

\section{Survey One: During the autumn (Qewi) Season}

The first survey was executed during the autumn season in the fields of Wazntet, Basheri, Awrari, Genfelom and then Hamelmalo. It was found that the diseases are occurred at different growth stages i.e. at seedling stage, vegetative, flowering and some were at harvesting stage.

The questionnaires were answered by the farmers in the selected orchards by the 1-5 disease rating scale method to calculate the disease incidence and disease severity occurred among the vegetables. 


\section{Sethumadhava Rao et al.}

The table 4 shows that the percentage incidence and percentage of disease severity of tomato, the least significant difference (L.S.D) among the farms and coefficient variation (C.V) between the observations, recorded in autumn season). The lowest percentage of disease incidence with 59.7\% was found at seedling stage, whereas, the highest percentage of disease incidence $97.8 \%$ occurred in Basheri at fruiting stage. The mean average of the first survey was $77.23 \%$. This shows that, almost $3 / 4^{\text {th }}$ of tomatoes cultivated in those villages were infected, at a particular growth period of the crop.

Table4: Percentage of Disease Incidence and Disease Severity of Tomato in two farms of five villages during Autumn (Qewi) season

\begin{tabular}{|l|l|l|l|l|}
\hline & \multicolumn{3}{|l|}{ Percentage of Disease Incidence of Tomato } & \multicolumn{2}{l|}{ Percentage of Disease Severity of Tomato } \\
\hline Villages & Farm 1 & Farm 2 & Farm 1 & Farm 2 \\
\hline Wazntet & 59.7 & 71.9 & 17.5 & 23 \\
\hline Awrari & 85.1 & 82 & 49 & 36.8 \\
\hline Genfelom & 70.2 & 78 & 29 & 25 \\
\hline Basheri & 97.8 & 66.6 & 82.9 & 19.6 \\
\hline Hamelmalo & 82 & 79 & 45 & 39 \\
\hline Mean & 77.23 & 36.68 & \\
\hline L.S.D & 20.98 & 33.76 & \\
\hline C.V & 15.5 & 52.4 \\
\hline
\end{tabular}

The lowest disease severity percentage was recorded in the two farms of Wazntet and Basheri villages with $17.5 \%$ and $82.9 \%$, respectively. The mean average for the disease severity is $36.68 \%$, which shows that, tomatoes cultivated in those villages at that particular time were comparatively not severe, except in the village Basheri which was devastating.

The graphical representation of both the percentage of disease incidence and severity of tomato shows among the villages during autumn season in figure 1. It is clearly indicated that percentage of disease incidence and severity was higher in Basheri, Awrari and Hamelmalo villages while lowest has been recorded in Wazntet village.

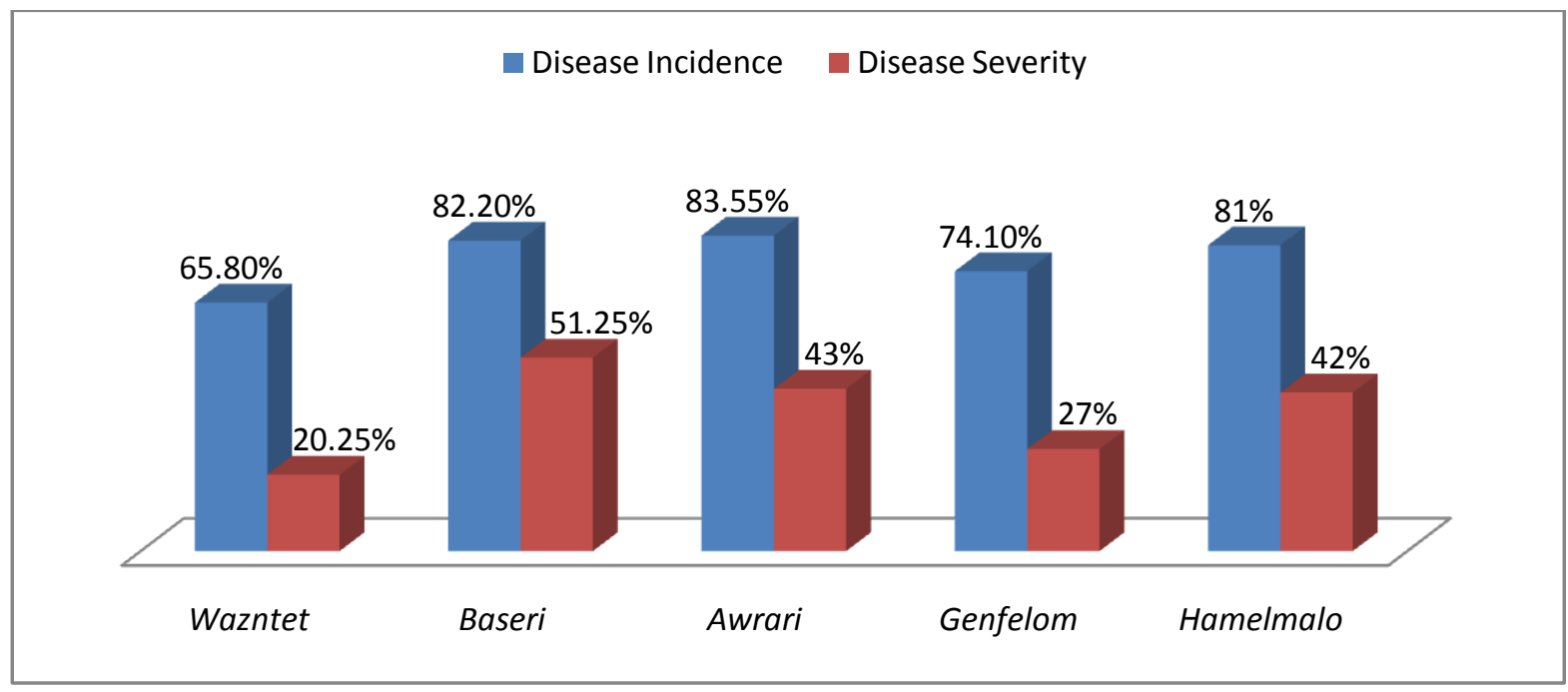

Figure1. The percentage of Disease Incidence and Severity of tomato in five villages during autumn (Qewi) season

\section{Chillies}

The percentage of disease incidence of chilli surveyed during the autumn season is shown in the table 5. The disease incidence was recorded lowest with $46 \%$ and highest with $97.4 \%$ in this sub Zoba. The mean average between the farms is $76.7 \%$, which shows that, more than half of the plants were infected by disease.

Table5. Percentage of Disease Incidence and Disease Severity of Chili in in two farms of five villages during Autumn (Qewi) season

\begin{tabular}{|l|l|l|l|l|}
\hline & \multicolumn{2}{|l|}{ Percentage of Disease Incidence of Chili } & \multicolumn{2}{l|}{ Percentage of Disease Severity of Chili } \\
\hline Villages & Farm 1 & Farm 2 & Farm 1 & Farm 2 \\
\hline Wazntet & -- & -- & -- & -- \\
\hline
\end{tabular}


Pathological Survey on Disease Incidence and Severity of Major Diseases on Tomato and Chilli Crops Grown in Sub Zoba Hamelmalo, Eritrea

\begin{tabular}{|l|l|l|l|l|}
\hline Awrari & 70.27 & 66.7 & 26.75 & 22.4 \\
\hline Genfelom & 93.5 & 97.4 & 62.9 & 66.4 \\
\hline Basheri & 95.2 & 94.6 & 75.3 & 56.6 \\
\hline Hamelmalo & 46 & 50 & 30 & 33 \\
\hline Mean & 76.7 & 46.67 & \\
\hline L.S.D & 5.826 & 16.47 & \\
\hline C.V & 3.4 & 15.7 & \\
\hline
\end{tabular}

The severity of chilies at any growth stages in sub Zoba Hamelmalo is minor, except in the village Basheri, (75.3\%) which was recorded extremely severe. It is recorded that the mean average was $46.67 \%$ of the disease severity of chillies. The minimum disease severity was registered with $22.4 \%$ in Awrari found at seedling stage, while the maximum rate of disease severity was with $75.3 \%$ which is found at fruiting stage.

The following graph represents, the disease incidence and disease severity of chili occurred among the villages, during autumn. The graphical representation in Figure 2 is clearly shown that the maximum range of disease incidence and severity reported in both Basheri and Gonfelom. There was no chilli production in Wazentet due to devastating disease infection of previous year.

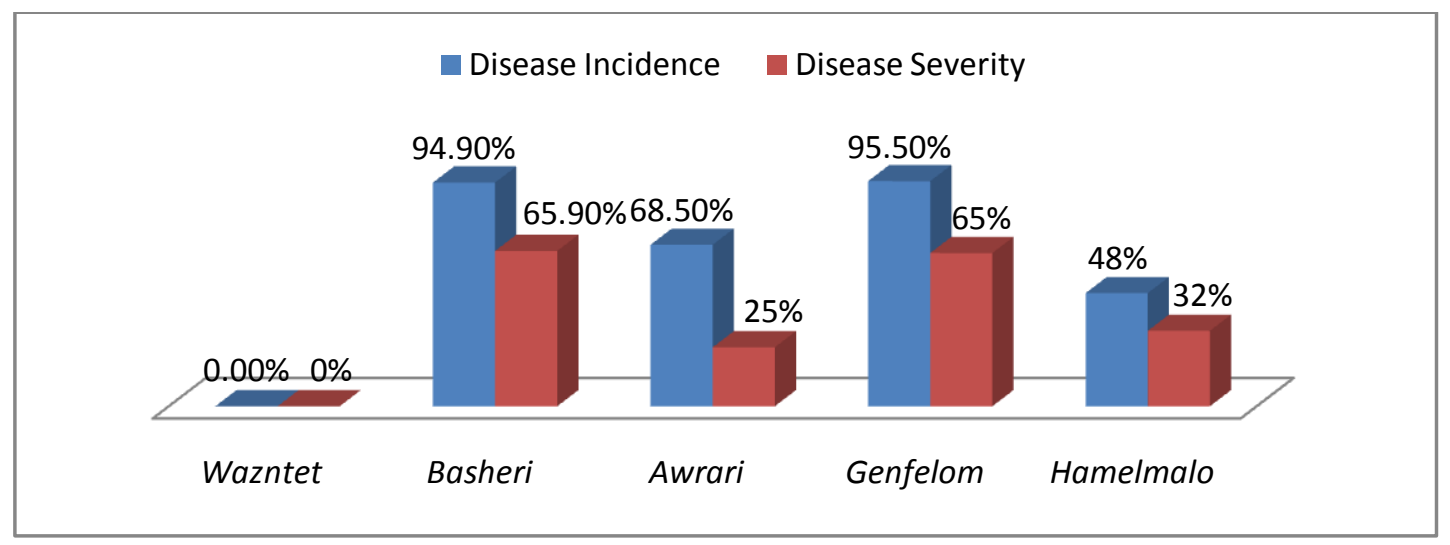

Figure2. The percentage of Disease Incidence and Severity of Chillies in five villages during autumn (Qewi) season

\section{Survey Two: During the winter (Hagay) Season}

The data has been collected in the second survey during the winter season at the time of their advancing in growth stage of vegetables. The samples have been collected from the selected fields of five villages for observation of the disease incidence and severity and were identified the pathogens.

Table6. Percentage of Disease Incidence and Disease Severity of Tomato in two farms of five villages during Winter (Hagay) season

\begin{tabular}{|l|l|l|l|l|}
\hline & \multicolumn{3}{|l|}{ Percentage of Disease Incidence of Tomato } & Percentage of Disease Severity of Tomato \\
\hline Villages & Farm 1 & Farm 2 & Farm 1 & Farm 2 \\
\hline Wazntet & 84.4 & 79 & 36 & 25.4 \\
\hline Awrari & 96.33 & 91.6 & 66.8 & 45 \\
\hline Genfelom & 89.3 & 92.3 & 41.4 & 43.3 \\
\hline Basheri & 78 & 80.4 & 20.4 & 22 \\
\hline Hamelmalo & 93.6 & 89 & 59 & 46 \\
\hline Mean & 87.39 & 40.56 & \\
\hline L.S.D & 5.196 & 12.63 & 17.5 \\
\hline C.V & 3.4 & 17 & \\
\hline
\end{tabular}

The disease incidence of tomato that observed during winter season was highly severe, with the mean average results $87.39 \%$. This shows that, almost the entire plants were infected. The minimum and maximum disease incidence percentages are $78 \%$ and $96.33 \%$, respectively. The highest rate of disease incidence was found at flowering stage and the least disease incidence, at seedling stage (Table 6). 
The percentage of disease severity of tomato during winter season was noticed with its mean average results $40.56 \%$. The lowest percentage was $20.4 \%$ and the highest was $66.8 \%$ that was observed in the village Awrari at the flowering stage.

Graphical representation of disease incidence and disease severity that were surveyed during the winter season is shown in figure 3. Although the result showed much variations in the incidence and severity of diseases of the surveyed area, the highest percentage of incidence is recorded in Awrari village while the lowest in Basheri. The findings of this survey clearly reflect that all fields showed disease incidence more than $70 \%$ whereas; disease severity is recorded between $20 \%$ and $60 \%$.

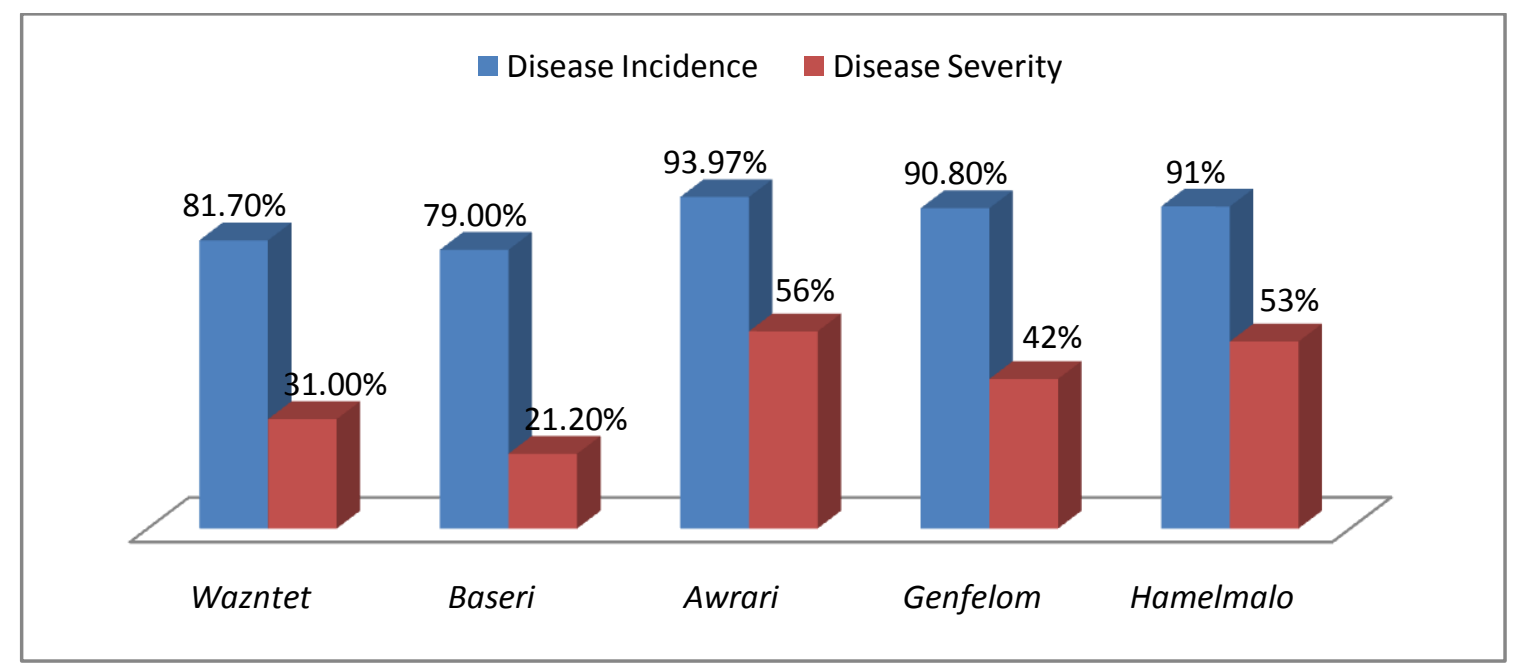

Figure3. The percentage of Disease Incidence and Severity of Tomato in five villages during winter (Hagay) season

The results reveal that the disease incidence of chili (Table 7) occurred in winter with the maximum and minimum at that particular time are $86.6 \%$ and $76 \%$ respectively. The mean average came out to be $81.78 \%$, in which was more than $3 / 4^{\text {th }}$ of the Chillies observed in the villages were infected.

Table7. Percentage of Disease Incidence and Disease Severity of Chili in two farms of five villages during Winter (Hagay) season

\begin{tabular}{|c|c|c|c|c|}
\hline & \multicolumn{2}{|c|}{ Percentage of Disease Incidence of Chili } & \multicolumn{2}{|c|}{ Percentage of Disease Incidence of Chili } \\
\hline Villages & Farm 1 & Farm 2 & Farm 1 & Farm 2 \\
\hline Wazntet & -- & -- & -- & -- \\
\hline Awrari & 82.2 & 85 & 29.7 & 31 \\
\hline Genfelom & 80.4 & 82 & 22 & 26.5 \\
\hline Basheri & 86.6 & 84 & 37.33 & 32 \\
\hline Hamelmalo & 76 & 78 & 45 & 49 \\
\hline Mean & 81.78 & & 34.07 & \\
\hline L.S.D & 3.85 & & 7.20 & \\
\hline C.V & 2.1 & & 9.4 & \\
\hline
\end{tabular}

The mean average for the disease severity of chili was $34.07 \%$. It is estimated that all Chillies were found diseased at seedling and vegetative growth stages, in the selected fields. The minimum percentage of disease severity was $22.0 \%$ while the maximum was $49.0 \%$ occurred in village Hamelmalo.

The graphical representation of disease incidence and disease severity that were surveyed during the winter season is shown in the Figure 4. Although the result showed much variations in the incidence and severity of diseases of the surveyed area, the highest percentage of severity is recorded in Hamelmalo village while the lowest in Genfelom. The findings of this survey clearly reflect that all fields showed disease incidence more than $70 \%$, however in Wazntet there is no chili production. 


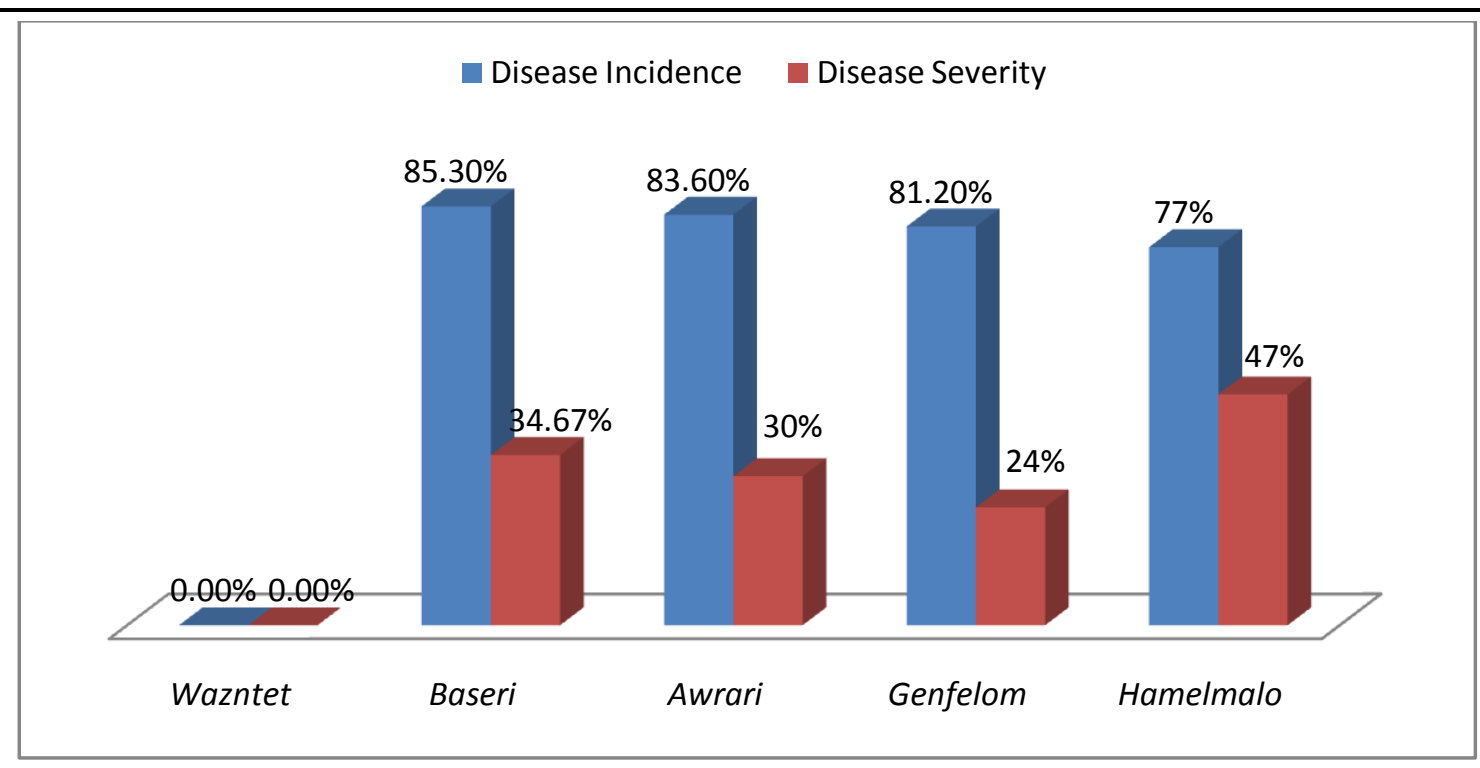

Figure4. The percentage of disease incidence and severity of Chilliesin five villages during winter (Hagay) season

Based on the obtained results of this present survey, it is clearly stated that the least significant difference (L.S.D) values show that, there were no any significant differences between the farms and villages. The following categories could be the main reasons, why they are significantly similar because the vegetables are at the different growth stages, and also the sample collecting fields are 6 $\mathrm{km}$ apart in some of the villages.

Educational Level: The farmers' educational level has a major affect in improving their total production and per capita income, by having majority control over diseases and insect pests. But almost all the farmers were illiterate. Among the farmers were surveyed, only one person has higher educational level, with $12+2$. Some of them follow informal education; the others got from their last descendants.

Cultivation Practices: Most of the farmers found in sub zoba Hamelmalo, use the same cultivation methods. If one farmer uses animal dung as a fertilizer, there is about $95 \%$ of probability that the neighborhood farmer uses the same fertilizer. To them, it is simpler to follow what other successful farmers do, rather than following scientific phenomenon.

Spacing: Tomato and chili require proper spacing in order to have healthy plant, quality of fruit and convenient farm practice. Generally, on the surveyed area, the common spacing followed by the growers for tomato and chili was 8 to $10 \mathrm{~cm}$ and 10 to $12 \mathrm{~cm}$ between plants respectively. But scientifically, it is more advisable to have 20 to $25 \mathrm{~cm}$ and 15 to $20 \mathrm{~cm}$ between plants for tomato and chili respectively, for profitable fruit production.

Irrigation: Irrigation has a great impact in setting the fruits and avoiding fruit drop at high temperature. Hamelmalo area is semi-arid regions that get an annual rain fall ranging from 350 to $670 \mathrm{~mm}$, thus tomato and chili would be benefited by irrigation during the dry period. In the area surveyed, the source of irrigation is under ground water, mainly the surface wells. The results of the present studies show that the frequency of irrigation depends on the availability of ground water and fuel for water pumps. Some of the farmers irrigate their land every 3 days and some every 5 or 8 days. The main reason having this difference is due to low supply of fuel and scarcity of water.

Chemical Control: Chemicals used by farmers in subzone Hamelmalo was pesticides like, Malathion which protects the vegetable from insect-pests. According to the farmers interviewed the chemicals are not easily available in the market and if available, they are very expensive that cannot be afforded by them.

\section{Conclusion}

During the survey, the disease incidence and disease severity has been recorded on tomato and chili, cultivated in sub zoba Hamelmalo during autumn (Qewi) and winter (Hagay) seasons. By this current survey it is showed that the major diseases and their causal organisms, observed in sub zoba 
Hamelmalo. Among all, the diseases occurred on vegetables some were due to fungal, some were caused by bacteria and viral infections and a few were affected by physiological disorders. These diseases were identified based on their symptoms occurred throughout the plant and the pathogen identifications were carried out in the laboratory of Hamelmalo Agricultural College. While carrying out the present survey, it was analyzed that there was no any significant difference between the surveyed areas, based on the diseases incidence and severity which is calculated at that particular time. The reasons for those results are educational level, cultivation practices, spacing, irrigation, fertilizer and manure application and use of chemical control.

\section{ACKNOWLEDGEMENTS}

The authors are thankful to the authorities of Hamelmalo Agricultural College, Eritrea for providing the laboratory and logistic support.

\section{REFERENCES}

[1] Choudhary B. R., Fageria M.S. and Dhaker R.S., A text book on production technology of vegetables, Second Edition, Kalayanic Publishers, New Delhi (2009).

[2] T. K., Kabir P., Dos and P.P. Joy., Tropical horticulture. Vol 2 Published by Naya Prokash, Calcutta, India. (2000).

[3] Osan, Central Highlands Irrigated Horticulture Development Project Completion Report Agriculture and Agro-Industry Department, January 2009.

[4] Ministry of Agriculture Asmara, August 1995

[5] Leipzig, Country report to the FAO International technical conference on plant genetic resource. Prepared by Ministry of Agriculture, Asmara, August 1995. (1996).

[6] Ministry of Agriculture, Annual vegetable production and consumption in Eritrea. (2012).

[7] Agrios, G.N. Plant pathology, 5th Ed, Department of plant pathology university of Florida, Elsvier Acadamic Press 30 Corporate Drive, Suite 400, Burlington, MA 01803, USA. (2005).

[8] Ministry of Agriculture Horticulture Division Report, Asmara, Eritrea. (2000).

[9] Jones J. B., Tomato plant culture, in the field, greenhouse and home garden. CRC Press, Washington, D.C. (1999).

[10] Anonymous, Annual average rainfall report zoba Anseba branch, Ministry of agriculture. (1997).

[11] ISTA., International Seed Testing Association. (1976).

[12] Aneja K.R., Experiment in microbiology, plant pathology and biotechnology. 4th Ed, New International (P) Limited Publisher, India, 121-128. (2004).

[13] Rifai, M.A., A revision of the genus Trichoderma Mycological papers (1969).

[14] Yonghao Li., Department of plant pathology and Ecology. The Connecticut Agricultural Experment station. www.ct.gov/caes. (2013).

\section{AUTHORS' BIOGRAPHY}

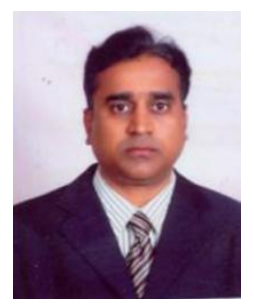

Dr. G. Sethumadhava Rao, obtained M.Sc. degree in Botany with the specialization of Mycology and Plant Pathology in 1993 and worked for $\mathrm{PhD}$ degree in the same field in 2000 from Osmania University, Hyderabad. He has 18 years experience of teaching in Plant Pathology, Mycology, Postharvest Management and Integrated Disease Management for PhD, P.G., U.G and Diploma Students in various Colleges and Agricultural Universities in abroad. Advisor/Co-advisor for four MSc students who obtained degrees and more than 20 students pursued their senior research projects under his supervision. At present, he is working as Associate Professor at Hamelmalo Agricultural College, Keren, Eritrea.

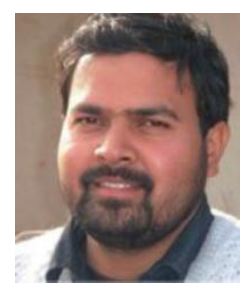

Dr. SyedDanish Yaseen Naqvi, PhD in Plant Pathology and Nematology from SHIATS, Allahabad, India joined as Assistant Professor at Hamelmalo Agricultural College, Keren, Eritrea in 2010. He has more than four years teaching experience at UG and PG level. He has published more than 10 research papers and authored 2 books on cereal, pulse and oil seed crop diseases. Sham Keflemariam; Haben Tesfagergish; Rahwa Tesfamariam and Tomas Habtemariam, are students and have worked in this senior research project. 